\title{
Remaking everything:
}

\section{the clash between Bigfoot, the termites and other strange miasmic emanations in an old industrial design school}

\author{
Zoy Anastassakis 1 \\ 1 Universidade do Estado do Rio de Janeiro, \\ Escola Superior de Desenho Industrial, Rio de Janeiro/RJ, Brasil
}

\begin{abstract}
This essay in speculative fabulation deals with the "ESDI Aberta" movement (2016-2017), in which students, alumni, professors and employees of the Superior School of Industrial Design, State University of Rio de Janeiro (ESDI/UERJ), have invested in alternative ways to live in difference, in response to the administrative and financial crisis that affects not only ESDI and UERJ, but all institutions of public education in the country. Accompanying the Esdian experiments with Donna Haraway and Tim Ingold, this essay suggests that the crisis affecting universities can be re-envisioned as an opportunity for resurgence and the collective production of spaces for living together in difference. Mobilizing notions such as correspondence and interstitial differentiation (Ingold), response-ability and sympoiesis (Haraway), it evokes the termites that occupied the campus of the school, the ex-Governor Luiz Fernando de Souza (Pezão), and other strange miasmatic emanations that have become unfastened from the buried Lagoa do Boqueirão da Ajuda.
\end{abstract}

Keywords: correspondence; speculative fabulation; State University of Rio de Janeiro; Superior School of Industrial Design; sympoiesis. 


\section{Refazendo tudo: o encontro entre Pezão, os cupins e outras estranhas emanações miasmáticas em uma velha escola de desenho industrial}

\section{Resumo}

Este ensaio de fabulação especulativa aborda o movimento "ESDI Aberta" (2016-2017), no qual alunos, ex-alunos, professores e funcionários da Escola Superior de Desenho Industrial da Universidade Estadual do Rio de Janeiro (ESDI/UERJ), investiram em formas alternativas de viver em diferença, em resposta à crise administrativa e financeira que afeta não só a ESDI e a UERJ, mas todas as instituições de ensino público do país. Acompanhando os experimentos esdianos com Donna Haraway e Tim Ingold, este ensaio sugere que a crise que vem afetando as universidades pode ser percebida como oportunidade para a ressurgência e a produção coletiva de espaços para o convívio em diferença. Mobilizando noções como correspondência e diferenciação intersticial (Ingold), habilidade de resposta e simpoiesis (Haraway), evoca os cupins que ocupavam o campus da escola, o ex-governador Luiz Fernando de Souza (Pezão), e outras estranhas emanações miasmáticas que se desprendem da soterrada Lagoa do Boqueirão da Ajuda.

Palavras-chave: correspondência; fabulação especulativa; Universidade do Estado do Rio de Janeiro; Escola Superior de Desenho Industrial; simpoiesis. 


\title{
Remaking everything:
}

\section{the clash between Bigfoot, the termites and other strange miasmic emanations in an old industrial design school}

\author{
Zoy Anastassakis
}

Avocado tree we will accept your act / we are also from the bush like the duck and the lion. Gilberto Gil, 1975

Distracted we will win.

Paulo Leminski, 1983

\section{Introduction}

This essay in speculative fabulation (Haraway 2016) deals with the "ESDI Aberta" movement (2016-2017), in which students, alumni, professors, and employees of Escola Superior de Desenho Industrial, Universidade do Estado do Rio de Janeiro [Superior School of Industrial Design, State University of Rio de Janeiro] (ESDI/UERJ) experimented with alternative modes of living in difference in the oldest industrial design school in Brazil. In response to the profound political and financial crisis that drastically affects not just ESDI and UERJ, but all institutions of public education and, more generally, life in the country, ESDI's community rehearsed forms of resilience and openness that came along with the cultivation of caring and community among those who inhabit that scholarly environment.

Following these Esdian experiments in the company of Donna Haraway and Tim Ingold, this essay seeks to contribute to the debate on the crisis affecting universities, suggesting that it can be reformulated as an opportunity for resurgence and the collective production of environments in which to cohabit in difference. Walking through the school, we will thus come into contact with the collaborative creative practices that have emerged in response to the precariousness of the UERJ stemming from its neglect by the government of the State of Rio de Janeiro. We will mobilize notions of correspondence and interstitial differentiation (Ingold), response-ability and sympoiesis (Haraway), through them evoking the termites that seized ESDI's campus, the State Governor, Luiz Fernando de Souza, known as Pezão ('Bigfoot'), and other strange miasmic emanations that are detached from the buried Lagoa do Boqueirão da Ajuda.

\section{Let me take you by the hand. Hey, honey, take a walk on the wild side!}

Plunging into the text 'On human correspondence', I hear Tim Ingold's call: 'Let me take you by the hand. [...] Hand and mind, after all, are inseparable, so, when I join my hand with yours, our minds also meet' (Ingold 2016: 09). I accept. Here we go. Hand in hand - he continues - our lives become linked, drawing together a zone of interpenetration, just like, as Marcel Mauss suggests, the one that involves beings in the midst of the deepsea currents. And he proposes: 'What if we were to join with Mauss and take the octopus and the anemone as exemplars for thinking about the dynamics of social life?' (Ingold 2016: 10). 
With this unusual invitation, which evokes the Maussian chorus of the 'Essay on the Gift', Ingold takes my hand and leads me to observe social phenomena à la Mauss: come, let us see human beings and groups in movement. Inhabiting a fluid medium, they behave in the same way as the tentacular beings from the deep sea. 'Thus hanging on to one another, beings strive to resist the current that would otherwise sweep them asunder, but in the midst of which they are nevertheless endlessly generated. That's what happens when I take you by the hand' (Ingold 2016: 09).

Lulled by this ocean wave blown by Ingold and Mauss, I allow myself to be taken on an underwater tour where I end up finding strange critters that, just like the octopuses and the anemones invoked by my travelling companions, get mixed up with one another in the sandy bottom of the sea. Joining them, I suddenly come face to face with the astonishing fluidity of social life. After all, we are warned by Mauss, revisited by Ingold (recalling Mauss), that if we set out to see things as they "really" are, what we see, then, are beings intertwined with one another in movement, as octopuses and anemones in the sea. Getting closer and intermingling their tentacles, these critters bind into a meshwork that becomes able to respond to the challenges of the ocean depths, the earth, and the sky.

Taking me by the hand, Ingold invites me to join Mauss, the anemones and the octopuses in the sea. Ingold invites me to think with lines:

To describe the meshwork is to start from the premise that every living being is a line or, better, a bundle of lines. How, then, should we describe the interpenetration of lifelines in the mesh of social life? One possible way would be to think in terms of knots (Ingold 2015: 13-16). A knot is formed when a strand such as of string or yarn is interlaced with itself or another strand and tightened. I suggest that in a world where things are continually coming into being through processes of growth and movement - that is, in a world of life - knotting is the fundamental principle of coherence. It is the way in which contrary forces of tension and friction, as in pulling tight, are generative of forms (Ingold 2016: 10).

In reply to this invitation, I propose a voyage to the city where I live, in the Southeast region of Brazil. Thus, we leave the Northern Sea towards the lower half of the Equator. However, due to a stronger current that insists on leading us astray, instead of taking the shortest route, southbound across the Atlantic, we are mysteriously taken up.

Crossing the Bering Strait, we are lured to the coast of California, where our tentacles mesh with those of Donna Haraway. Creating an unexpected meshwork, we descend the Pacific Ocean, circumventing the American continent, until we return to the Atlantic again, this time in the Southern Hemisphere. Finally, after a lengthy circumnavigation of the American continent, we reach the Brazilian coast, and dock in Rio de Janeiro. Upon entering the Guanabara Bay, we see the Museum of Modern Art, where, in the 1950s, artists, intellectuals, and politicians dreamed of building a school of industrial design. Exhausted after such a long journey, we decline to visit the museum, but advance a little further, to the marshy waters of the buried Lagoa do Boqueirão da Ajuda, where, in 1779, after an outbreak of influenza and fever that affected a large part of the population, the Viceroy of the State of Brazil, D. Luís de Vasconcelos, ordered a French-style public garden to be built.

As the first urbanized area of Rio de Janeiro, a manifesto for the Enlightenment's concept of public health, the Passeio Público ('Public Promenade') was intended to found a new relationship between man and nature in the city. Its creators dreamed that the wild nature that had reigned over these lands, once a source of fear, would thenceforth be reinvested as a product of knowledge and planning. After all, even before the development of the microbian theory of disease in the second half of the XIX century, European medicine associated epidemics to the impurity of the air, the miasmas, originated by people and the exhalations of sick animals, of the swamp's emanations and of decaying substances (Martins, Martins 2006). According to this theory, once the miasmas were detected by their bad odour, their propagation could be interrupted, and it would then be possible to avoid and prevent epidemics. 
In its original Greek sense, the term miasma is related to impurity, stain. Corrupted, spoiled air. Or, as described by the physician Giovanni Maria Lancisi (1654-1720), the miasma was composed of certain harmful influences emanating from the swamps (apud Martins, Martins 2006). In the turn of the nineteenth century, in the midst of the crusade against the miasmas and for the purification of the environments, a strong concern for water quality arises. Boiling, use of chlorinated compounds, acidification and carbonization, and, at the limit, on an urban scale, landfills: these are some of the resources exploited for environmental sanitary control.

However, the waters of Lagoa do Boqueirão, which had once flowed into the sea, persist. With the summer rains, the Parque and Rua do Passeio which it opens on to, are still flooded by the muddy waters of the lagoon, which stubbornly insist on returning to their place. As they do so, they advance through the entrance of the campus where, in 1962, the Escola Superior de Desenho Industrial was installed, and where the story I will now tell you begins.

But the one who tells this story is not the same as she who took a dive into the Northern Sea. Upon returning to my city, emerging from the water in the centre of the muddy Boqueirão, I find myself metamorphosed into a strange and miasmic creature, perhaps resembling a spider, an octopus, or a coral. My sticky tentacles do not cease to multiply and, in this movement, I tie myself not only to Donna Haraway, Tim Ingold, and Marcel Mauss. Alongside them, I wrap myself around other critters such as Jeanne Favret-Saada, Starhawk, Isabelle Stengers, Bruce Albert, Davi Kopenawa, Ailton Krenak, Ibã Huni Kuin, Stuart McLean and Carlos Castañeda. Confabulating with them, I revisit the school with its echoes of the thousand and one stories that, at one point or another, took place there. As a tentacular critter, I sense the presence of some of the chthonic beings that inhabit it. They emanate the miasma that reaches me, whispering stories of experimental futures. I dwell on them, to listen and to tell.

Seeking a little sun, I gather strength to rid myself of the muddy waters of the Boqueirão, and finally rest, before beginning our story. But, dazed in the midst of the confusion of tentacular thinking (Haraway 2016) that flows through me, I neglect that old preoccupation of trying to control mistakes (Viveiros de Castro 2004), and settle comfortably into the space of equivocation where I dwell lazily. This is certainly not the story of the history of a Brazilian industrial design school. Nor is it an account of how, in this strange place, urbanization, modernity, and industrialization became allies of the white men who settled there, creating colonies of exploitation. This is just an attempt to communicate, by difference, one version among innumerable versions that emanate abundantly from this place. It is another story, one which deals with miasmas, chthonic critters, tentacular thinking, metamorphoses, correspondences, entanglements, interstices, rehabilitations, resurgences, restarts, reinventions.

\section{Walking hand in hand with Donna Haraway and Tim Ingold through an old industrial design school, we visit the termites that inhabit it}

Back to the beginning, in the early 1960 s, I invoke a young German who had just graduated with a degree in design, crossed the Atlantic and, like my companions and I, ended up in the same design school at Rua do Passeio, number 8o. Fifty-seven years later, in a speech held in his honour during a ceremony at ESDI on July 2017, designer Karl Heinz Bergmiller commented: 'At ESDI, the trees tell the history. I went to plant them. I identify with them'. With this statement, the former student of the Hochschule fur Gestaltung from Ulm mentions a dozen rubber trees (Ficus elastica) and tropical-almond trees (Terminalia catappa) found on the campus of the first higher-level school for industrial design in the country, ESDI, created by the government of the State of Rio de Janeiro (Guanabara State, at the time) in 1962. 
Provisionally installed in an old complex of small military buildings located in the historical centre of the city, the school continues to operate in the same facilities to this day. When the area was being renovated so that the new school could be established, the trees had not yet been planted. Some alumni recalled that planting had taken place between the end of the 1960s and the beginning of the following decade, at the initiative of the then director, the engineer, urbanist, and feminist Carmen Portinho (1903-2001).

Today, the tops of these trees reach great heights, and spread out producing shade over much of the campus. Their aerial roots rediscover the soil, forming auxiliary trunks. Underneath the earth, they create a meshwork that unfolds throughout the subsoil, pushing against the houses and their walls. One of these roots even climbed the roof of a neighbouring building, invading its water reservoir. In treading this path, it caused cracks to appear in the floor of the auditorium where the tribute to Professor Bergmiller was held, as were many other classes and conferences by people like Vilém Flusser and Umberto Eco.

It is known that the pollination of the Ficus depends on a specific wasp that has developed in a long process of exchange with this plant. More than simple interactions among distinct living beings, exchanges such as these tell us of what Donna Haraway calls symbiogenesis, or sympoiesis - 'making-with' (Haraway 2016: 5). Through these terms, she discusses processes that unfold through long periods of intimacy among strangers, 'practices of critter becoming-with each other at every node of intra-action in earth history' (Haraway, 2016: 6o). Thus, according to her, these symbiotic agencings are more like entanglements than entities. Considering this interpretation of the exchange processes between beings of distinct species, symbiosis is not a mere synonym for mutually beneficial relationships, since the partners do not predate the entanglements. They are beings-in-meeting and, therefore, are consequences of these entanglements.

Recalling Bronislaw Malinowski, who. like Haraway, described social life as a long conversation, Ingold argues that 'there is no reason for such conversations to be limited to humans, or even to living things. Nor need humans to be at the center of it' (Ingold 2017: 32). Taking into account their arguments, one must then consider that 'the collaborations among differently situated people - and peoples - are as crucial as, and enabled by those between the human and animals' (Ingold 2017: 16).

But how does one learn to listen to the wisdom of these other inhabitants of the world? Thinking about this, Ingold relates the notions of correspondence and sustainability.

The problem in our relations with the natural world, then, is that we have forgotten how to correspond with the beings and things of which it is comprised. We have been so concerned with the interaction between ourselves and others that we have failed to notice how both we and they go along together in the current of time. This, surely, is what sustainability means: not the perpetuation of a completed form or stable state but the capacity of keep going, to carry on, to endure. If interaction is about othering, then correspondence is about togethering. It is about the ways along which lives, in their perpetual unfolding and becoming, answer to one another. This shift from interaction to correspondence entails a fundamental reorientation, from the between-ness of beings and things to their in-between-ness (Ingold 2017: 41).

Taking seriously Karl Heinz Bergmiller's speech and his statement of sympathy (Ingold 2016: 13) toward the trees planted by him and Carmen Portinho at ESDI, I thus propose to move closer to this old school of industrial design through the account of these and some other strange sympoietic relations that I was able to perceive between 2016 and 2017. At the time, the school and the university to which it belongs were seriously threatened as a result of a political, financial and institutional crisis which had been affecting not only the State of Rio de Janeiro, but Brazil as a whole.

Interweaving the arguments of Ingold and Haraway, I then embark on a narrative essay that intends to be speculative and imaginative while still documentative and realistic. In Haraway's terms (2016), I compose a speculative fabulation, which emerges as I try to follow the tracks of a series of multi-species encounters 
taking place at ESDI. This narrative experiment is organized around some of the knots formed by these strange encounters. Observing them, following the lines that conform them, is, then, my aspiration.

In framing the notion of correspondence, it is Tim Ingold, once again, who invites us to think in terms of knots:

A knot is formed when a strand such as of string or yarn is interlaced with itself or another strand and tightened. I suggest that in a world where things are continually coming into being through processes of growth and movement - that is, in a world of life - knotting is a fundamental principle of coherence. It is the way in which contrary forces of tension and friction, as in pulling tight, are generative of forms (Ingold 2016: 10).

To activate such a state of attention, one must be present. Watch and listen. In Ingold's terms, this means to care. To care for others. According to him, this attentionalty is what allows us to perceive the textures shaped by the entanglement processes between alteration and conjunction. With Haraway once more, we cannot fail to consider the dangers involved in this kind of listening: "The risk of listening to a story is that it can obligate us in ramifying webs that cannot be known in advance of venturing among their myriad threads" (Haraway 2016: 132).

According to this author, escaping this trap requires paying attention to the situational and contingent aspects of each of these stories. In order to do so, however, it is not enough to be attentive and to listen. By listening and paying attention we are also invited to tell stories. Situated stories that speak of risky cooperation (Haraway 2016: 14), but that are also speculative fabulations like those sympoietic processes in which multispecies companions engaged in combining their lives give birth to unexpected collaborations and combinations (Haraway, 2016: 04). Comprised of many versions, 'These are stories in which multispecies players, who are enmeshed in partial and flawed translations across difference, redo ways of living and dying attuned to still possible finite flourishing, still possible recuperation' (Haraway 2016: 10).

Playing thus with textures, meshworks, knots and lines, science fictions, speculative fabulations and string figures, Haraway and Ingold invite us to tell stories that simultaneously involve processes of remembering and imagination (Ingold 2016: 21). In Haraway's terms, stories that speak of making strange kinship (Haraway 2016: 02), meaning 'something different/more than entities linked by ancestry or genealogy' (Haraway 2016: o3). Ingold, in his terms, challenges us to 'find a different way of writing, (...) to experiment: try things and see what happens' (Ingold 2017: 81). Thinking with them, a question arises: how to tell stories such as these, full of in-between-ness (Ingold 2015: 147)? Let's see.

At ESDI, the Ficus do not only establish symbiotic relationships with pollinating wasps, but also, and quite intensely, with the termites that have taken over the campus through the years. Over the walls, made of brick and concrete - materials that they attack without necessarily ingesting - these chewing social insects have built channels and roads, weaving a complex meshwork that takes them to their true food: cellulose.

Living with microorganisms capable of digesting cellulose and other organic compounds, termites can literally live inside the food: be it in the subsoil, in the trees, windows, doors, or on the worktops where the students develop their exercises. This companionship between termites, bacteria, and protozoans, along with their great abundance in ecosystems, enable these insects to act as super-decomposers (Wikitermes 2017). At the same time as they speed up the decomposition of organic materials, they help to aerate the soil.

After the termite occupation of the school, when doors, windows and table tops that at first glance appeared intact were touched and analysed more closely, they turned out to have been remade from the inside. Instead of wood, there was a new material produced through trophallaxis, a procedure to recover those microorganisms with which termites develop companionships that sustain their way of life. 
Trophallaxis is understood as the feeding process whereby one individual makes available to another what is inside its own digestive tract, either orally or anally. Feeding on material regurgitated or excreted by other members of the colony, termites nourish themselves by recovering the bacteria and protozoa that are able to digest the cellulosic materials. For termites, participation in this collective feeding system is fundamental, since during the exchange of the exoskeleton (ecside) - the membrane in which the symbiotic microorganisms are housed - is lost, which causes the reduction of these multispecies exchanges, a condition for the feeding diversity resulting from this intricate symbiotic relationship.

However, more than mere nutritional exchange, trophallaxis must also be considered a form of communication, which results from the transmission of chemical messages, drop by drop. When the mandibles of two termites come into contact, a small drop is released from the mouth of one of them toward the other. 'A fraction of a second and the message has already been given' (Tinoco 2016). In addition to trophallaxis, there is another typical communicative behaviour among the termites, grooming, in which individuals lick each other. This is also a mechanism for eliminating microorganisms and foreign particles that can cause illness among members of the colony.

But the specificity of the termite's lifestyle does not end there. These critters are not just vegetarians, they are also cannibals (Fontes 2014). After all, they consume the tegumentary remains of their ecsides, and may also cannibalize individuals that are traumatized, weakened, or those who deviate from the population standard. Such voracity for animal matter also results in the consumption of small invaders, who enter the nest and end up being killed.

Their nests, constructed with a mixture of soil, faeces, saliva, and wood particles (Castro Júnior 2002), may contain hundreds to thousands of individuals. In them, many other animals can also be found, including different kinds of termites, the inquilines. There are termitophiles, animals living with termites inside the galleries, and termitarophiles, which only use termites' nests without associating with their inhabitants, including beetles, spiders, lizards, rats, birds etc.

Among all these companion species, it is worth highlighting the protozoans that live inside the termite's intestine, which form very close symbiotic relationships with different types of bacteria. They don't just help termites digest cellulose. Without them, the termites could not survive, since their lives are mutually constituted through these meetings and entanglements that shapes them to be dynamic multi-partnered entities (Haraway 2016: 64) 'that hold together, develop, communicate, and form layered tissues like animals do' (Haraway 2016: 65).

Following Lynn Margulis, Haraway proposes that we follow the symbiogenetic models shaped by these knots or symbiotic groups, the holobionts (Haraway 2016: 62). In her view, we can formulate models that allow us to follow what really matters, namely the relationalities that abound in the midst of the movements of formation of complex ecosystems, the holobiomes.

What makes this proposal so fruitful for reading the situation in ESDI is that by emphasizing the relational aspects of social life, Haraway and Ingold invite us to observe not only what we believe we know - things as we understand them to be - but also the intervals wherein the unsuspected sympoietic practices respond skilfully to the challenges presented to them for living in a damaged planet (Haraway 2016: 67). Entangled, we become able to stay with the trouble, committed not to great ends and new beginnings, but to 'partial healing, modest rehabilitation, and still-possible resurgence in hard times' (Haraway 2016: 71).

With Ingold and Haraway, we can speculate on the partial connections (Strathern 1991) that abound in the continual encounters of all these companion species. With that, we can consider the issues that matter, which are not limited to the way animals stay together, but rather deal with how they craft architectures and spaces that stimulate the astonishing processes of morphogenesis (Haraway 2016: 66). 
Beyond a mere interest in the social life of trees, termites and their companions, with this story I propose to think what they effectively do while living with us, humans, in ESDI. And, moreover, what they propose to us with their presence, and in return, how we - professors, students and employees - correspond (Ingold $2015,2016,2017$ ) to them and to the architectural symbioses they devise, as we continue living our school life.

This raises the following questions: what does our awareness of their presence, and subsequent efforts to prevent them from continuing to devour the school, tell us about who we are and what we may become, as well as about the ways in which we rehearse responding to the crisis that has been affecting us in ESDI, UERJ and, in broader terms, public universities in Brazil? What does this awareness lead us to perceive about this old industrial design school and the ways in which it has been responding to the time and care given to it by those who have been and have passed through there over the past 55 years? In what way do these responseabilities (Haraway 2016; Ingold 2016, 2018) rehearsed in ESDI suggest new ways of being and making a school?

These issues matter because a university is not only made up of schools, colleges, institutes, and departments, where students, professors, and employees live together, but also of cement, wood, metals, doors, windows, roofs, tables, chairs, computers, wires, tubes, water, electricity, earth, trees, grass, and - in the case of ESDI - mites, wasps, mosquitoes, spiders, centipedes, dogs, cats, termites and all the microorganisms that share life with them.

So, with Ingold and Haraway, it is possible to think of the school as a holobiome, composed of a series of knottings and joinings that form a meshwork, whose constituent lines are drawn by dynamic multi-partnered entities (Haraway 2016: 64). In this sense, the school is a place that is in the world at the same time that it makes worlds, and it is therefore never finished, defined, closed. On the contrary, it is an environment in continuous growth that is perpetually transformed amidst the movements of its inhabitants, living together in difference and in co-living.

Thinking about the presence of termites and trees beyond the troubles they pose in terms of maintaining the buildings that make up the campus of this old school is not the aim of this essay. To my understanding, it is possible to speculate, along with the trees, termites and their companions, on other relationships that demanded a capacity for sudden response in ESDI. For example, another knot was created by the entanglement of the political and financial crisis in the State of Rio de Janeiro and the maintenance of academic activities in UERJ and also there, in ESDI.

Following a clue from Marilyn Strathern, taken up by Haraway, that points to anthropology as the knowledge practice that studies relations with relations, putting other relations at risk (Strathern 1991 apud Haraway 2016: 11), I now propose a rapprochement with some other rolls, knottings and joinings, formed in the midst of the responses of professors, employees, and students of ESDI to political-administrative disturbances between 2016 and 2017.

\section{Crouching down to follow Big Foot's tracks, we meet some other chthonic critters that live in this place}

In March 2016, I became the director of ESDI alongside Professor Marcos Martins. In UERJ, deans and school and institute directors are elected directly in a process that involves students, professors and staff. During ESDI's electoral period at the end of 2015, no tickets announced their candidacy to dispute the direction of the school. In response to this silence, the then-director wrote a letter to the professors summoning them to a meeting, urging them to consider the possibility of forming a ticket.

A few years earlier, the director had set up a task force to revise the curriculum of the undergraduate course in industrial design. This group was composed of the new teachers who arrived at ESDI through public tender to occupy the vacancies created by the retirement of some older teachers of the school. In 2011, 
after defending my doctoral thesis in anthropology (Anastassakis 2011, 2014), I applied for one of these vacancies and was approved as an assistant professor in the field of design, society and history. As soon as I started to teach, I was invited, along with some of the other new teachers, to participate in the group that would be responsible for the elaboration of the new curriculum.

Concerned with the completion of this process, Professor Marcos Martins, who had also recently been hired, and I finally decided to run on a ticket for the direction of the school. However, this decision was only taken after a proposal I presented at that meeting: I called on the teachers to donate hours of work for school administration, in addition to regular teaching and research hours, with no extra gratification. At that moment, it seemed to me that no one intended to run the school because that task sounded extremely heavy and lonely. I imagined, then, that if there was a distribution of work and responsibility, there might be some proposal for an application. I appealed to the fellow teachers present at the meeting. However, no one applied. At the end of the meeting, it seemed to Marcos and I that if we did not submit our own application, all our ongoing effort toward the elaboration and implementation of a new curriculum would be threatened. We decided to apply.

Once elected, we began a series of attempts to decentralize the administration. We delegated to a third professor the management of funds that the university passes on to the school for small quotidian costs. We redistributed the tasks among the office staff and requested from the central administration an employee to oversee campus administration. We invited a professor to oversee the facilities and to monitor the infrastructure that aids academic activities. Finally, we set up ESDI Lab, a students' cabinet that began to collaborate with the directors, dealing with issues on two fronts: redesigning of the school's communication: visual ID, institutional letterhead, wayfinding and website; 2) occupying spaces: mapping resources and activities specific to each part of the school, proposing and carrying out changes to this organization.

Initially composed of eight undergraduate students, this laboratory contributed in a vital way to the installation of a new environment within the school, since its members began to speak and act with and for the directors, amplifying, horizontalizing, and decentralizing relations with regular administration, but also, and above all, gathering proposals, rehearsing and putting into practice new and old ideas and projects. We realized that, if multiplied, this wave of care could create a kind of force-field (Ingold 2011) capable of reactivating the sense of community in the school in other, unsuspected ways. This became even more important in the face of the enormous political, financial, and institutional crisis that already affected us.

One of the first activities after we assumed our posts was an inspection of ESDI's campus, which I had not visited attentively since my student days in the 1990s. I was very impressed with the deterioration of the facilities, which appeared to be overwhelmed by the action of time, plants, and termites that had spread everywhere. Apart from my astonishment, we understood on that visit that it would first be necessary to invest in pruning the trees and containing the termites. We looked for the municipal body responsible for the parks and gardens, requesting a technical report on the condition of the trees on the ESDI campus. Some professors argued for the total elimination of the trees situated next to the houses that hold the school's main facilities. But my view was that we should prune only what was necessary, paying particular attention to the risks of falling branches on roofs and trees that were already devoured by termites. Fortunately, the report recommended minimum pruning, condemning only two avocado trees that were hollow, devoured by termites. One of them threatened to fall on a wall that separated ESDI from the music school of another university next to us.

Regarding termites, we contacted a specialist in isopterology, a retired professor at a public university, who provided fumigation services. During campus visits, we were introduced to the silent and invisible work performed by these creatures, which had transformed the interior of doors and windows into other unsuspected things. The termites seemed to be careful not to gnaw outer surfaces, devouring interiors while adding a new 
material composed of saliva and excrement. Thus it was still possible to find doors, windows, and table tops in the classrooms. However, inside, they were no longer made of wood. In its place, this strange material was produced by the collaborative effort of termites and their intestinal companions.

So, what still seemed to be a school was already the same and something else. Another school, seemingly hollow, but remade by a new materiality, had been slowly built by the invisible and silent work of our termite companions. If, as administrators, we had to counteract the action of these critters and invest in ways of restoring what they had damaged, our contact with this other architecture, produced by them and their companions, would also launch us into a series of questions related to the novelty that presented itself by that (dis)architecture. What other new stories did this symbiotic architecture invite us to build now?

If, as Bergmiller reminds us, in ESDI the trees tell the history, then we must consider what stories we are willing to hear from them. Moreover, what stories do we decide to honour: the one with which this founderprofessor, to whom we paid homages twice in 2017, identifies? Or would it be Director Carmen Portinho, the engineer, urban planner and feminist activist, who planted the trees with students in the 196os? Would it be the one told by the tentacular roots of the trees that venture through the city in search of water, or the termites' story of living with bacteria and protozoa that develop imbricated ways of life and remake materialities with them? Or the ones experienced by more than a thousand designers trained at ESDI? Would it be the story of $45 \%$ of students who entered the university through a state policy that reserves vacancies for students from public schools, blacks, people with disabilities, and members of ethnic minorities, as well as the children of civilian police, military, military firefighters, and of security inspectors and penitentiary administration, dead or disabled in service - a policy of which the UERJ is a pioneer in the country? Or, perhaps, the story forged by Governor Luiz Fernando de Souza, better known as Bigfoot, head of the administration of the State of Rio de Janeiro from 2014 to 2018 ?

After a moment of euphoria following the announcement of the discovery of oil reserves in the pre-salt layer of the ocean floor in the Rio de Janeiro region, the state plunged into a deep financial-administrative crisis. UERJ, a public university linked to the state administration, of which ESDI is part, was affected in an intense and unprecedented way. The state government, which is responsible for the transfer of funds for maintenance and academic activities in UERJ, defaulted on salary and scholarship payments, as well as on funding for infrastructure maintenance and regular teaching and research activities. From early 2016, delays and suspensions of payments became recurrent and cumulative. But even in 2015, the government had neglected to uphold contracts with companies that provide outsourced services in security, food, cleaning, maintenance, and garbage collection.

This resulted in a series of strikes by teachers, students, and staff, as well as the temporary suspension of activities after decisions by the university's central administration, due to lack of water, power, maintenance, and services. In the midst of this situation, cases of illness, stress, depression, and other physical-emotional complications multiplied. The scale of debt, firings and requests for the retirement of teachers and employees, grew. The number of applications for student transfers to other universities increased and the search for undergraduate and graduate courses declined.

In ESDI, the crisis immediately caused a reaction in students, alumni, teachers, and volunteers who mobilized to defend its survival. In 2017, this movement was named "ESDI Aberta", an expression that was launched in an event that marked the inauguration of new means of access and communication for the school. Professor Luiz Pereira de Souza, alumni and former director of ESDI, comments: 'we had a big meeting to defend the school in which all generations that had/have been there were present. It became clear that even though conservative and backwards thinking insists on demonizing public, secular, and free education, we will prevail over it. They will pass and our ideas will remain' (statement for the author). 
Resisting institutional and financial precariousness, keeping the school open became a continual exercise in shared management between professors, students, and staff, in which we rehearsed survival during the crisis. In addition to efforts towards decentralization, distribution, and horizontalization in the leadership and administration of the school, several experiments emerged as alternative ways of opening up and maintaining activities. One group of students opened a plot of land for a community vegetable garden where, along with their horticultural activities, they started to develop products and research with organic materials. Another group occupied the graphics lab that had been deactivated due to the absence of technicians, creating "Colaboratório", an experiment involving artisanal printing, shared management, machine hacking, book-making, and other graphic arts. Professors, students and alumni came together to offer courses, reserving $50 \%$ of the vacancies for Esdi students and whole days of classes and workshops open to the general public with theme defined with the students. Yet another group of students came together to enable the payment of the monthly salaries of the groundskeeper, Mr. Carlinhos, who was fired from one of the companies that terminated their contract with the university. These are some examples of actions taken in the effort to survive and open the school up at that time.

Along with these initiatives, organized in ESDI, the university also created means for community management during the crisis. With increasing delays in wage payments, scholarships, and funding, the central administration mobilized the unit directors' forum, which met weekly. This was not so much for routine discussions of how the university could respond to the government, but above all so that everyone could keep abreast of the situation in each of the academic units and the various campuses where they are installed.

In these long and repetitive meetings, each director brought news of the operating conditions in his/her unit. The rectory asked us to present reports about the conditions for teaching, research and administration activities, but also to report on community assessments which resulted from periodic meetings between teachers, students and staff in each academic unit, so that the whole university could be aware not only of the working conditions, but, above all, of the "pulse" of the community. The intense toing and froing of these countless meetings, where most of the time there was nothing to be deliberated, was causing anguish in many of us. However, the effort to maintain communication amid an increasingly complicated crisis was fundamental to the activation of a strong sense of community in UERJ and also in ESDI.

This tense process intensified in the first days of 2017, when the central administration declared that it was impossible to resume classes due to a lack of resources and basic services. This decision gave rise to a wide-ranging debate across academic departments on possible alternatives, in the hope of avoiding a complete shutdown of activities at the university.

As we debated what to do at one of these meetings at ESDI, an office clerk asked to speak and argued that we should lock the school and wait for it to fall apart. In his view, this was the only way to make 'public opinion' aware of the crisis that was affecting us. To this a computer technician pondered: 'If we close the school and let it fall, it will be left to us, and only us, to remove the debris and clear the ground to resume activities, even more precariously'.

At that moment, it seemed as if no one cared about the university. We struggled to get attention. Many argued that the best way to deal with the crisis was to galvanize 'civil society', seeking support from 'public opinion'. We pondered the gains and losses involved in closing or opening the university. The debate was constant. Despite the great tension that surrounded it, the environment was open to discussion. Most of the time no decision-making or voting was involved, which ended up establishing an atmosphere of motivation and engagement among those who, like the computer technician, were willing to keep the school and the university open and operating, even in an improvised and partial way. 
In the midst of these meetings, we decided, at ESDI, that it would be important to mobilize not only the current community, but also the alumni, reactivating the association of friends of the school. We sought to extend the care, make the crisis visible, and to celebrate, with a big party, the opening of the new access gate to the campus and a website, both carried out through partnerships established in 2016. The event, called 'ESDI Aberta \#UERJ resiste' was scheduled for February 12, 2017.

The movement quickly expanded when former student, composer and writer Nelson Motta, a columnist for a major newspaper, published an article denouncing the threat of closure. A meeting was then organized with the presence of many alumni, who gathered in a task force to raise donations to fund urgent infrastructure costs - and to organize the party. Thus, a new group became responsible for gathering donations and organizing the event. We then had periodic meetings not only to deal with the crisis, but also to prepare for the celebration.

But why celebrate? We talked a lot about this, and we ultimately understood that, faced with instability, in which any kind of articulation to escape the precariousness of the university seemed impossible, the best we could do would be to affirm our presence in that place, to remind ourselves and others that ESDI existed and would continue to exist. To celebrate, and not only to remember, what shapes us as a community, but also to entice and prolong into the present what would vanish without the active reciprocity of partners (Haraway 2016: 25).

Two concrete reasons animated the party: opening a new gateway to the campus and launching a new website, both projects made possible through partnerships with students, alumni, and public and private institutions. The event entailed art and design workshops, collective planting, graffiti, a charity bazaar, food and drinks fair, 'dis-conferences', an homage to Prof. Bergmiller, a lecture by Prof. Pedro Luiz Pereira de Souza, the inauguration of the new entrance, website and visual identity, in addition to a concert bringing together various artists, and, to finish off, a Carnival parade. Over 1,500 people passed through ESDI that day, and there was significant repercussion in local media and social networks. Different generations of alumni reunited and the wave of community care spread beyond the party. In the weeks that followed, many former students returned to school, proposed partnerships, and engaged in various activities. Several proposals to ensure the school would stay open were thus rehearsed, and many were tested throughout 2017.

We were aware that none of this would 'solve' our main problem, nor would it guarantee that the school would stay open. Nor were we expecting that ESDI could become anything other than a school. We did not seek to be something else, but rather for ESDI to remain an industrial design school of its time. If it was a time of ruins, how do we proceed? How would we correspond to a time of precariousness, in resurgence?

On March $14^{\text {th }}$, a group of about forty students decided to occupy the school and to live in its quarters. This occupation, which they called "OcUPA ESDI", also involved students from the group that had been working with the directors. In the middle of the afternoon, they entered the director's office, where some professors were gathered, and informed them of the beginning of the occupation. Later on, that evening, in a declaration published on social media and affixed in the classrooms, they stated what motivated them:

We, a group of ESDI students, decided to start an occupation movement today, 03/14/2017. Due to the systematic delays and non-payment of employees, scholarships and maintenance funds for UERJ's infrastructure, we agree with the position of the board of directors, which has declared that it is impossible to return to the regular functioning of the university. At the same time, emptying of the university puts at risk the very existence of these spaces. With the community fragmenting, seeking individual solutions, the sense of the collective good is lost. Given this scenario, we understand that an occupation is an alternative that can foster activities of creation and transmission of knowledge applied to this reality. This being the essence of the university, it is our true tool to reintegrate the community in defence of public and popular education (OcUPA ESDI 14/03/2017). 
They began to spend the nights in one of the classrooms, and demanded a space to cook. We asked the university to authorize the installation of a stove in our facilities, and we communicated to the central administration the profound confidence that the directors had in the group. However, with this occupation, there was a significant change in the relationship between the directors and the group of students who, until then, had been collaborating with them. Without abandoning their posts, these students began to organize their own agenda and priorities with the other occupants, no longer as a group that only supported the directors. While they declared support for the positions of the directors of ESDI and the board of directors of UERJ, they also asserted their autonomy in the face of the established structure of the school administration. By creating a new instance of action and housing it in that place, they contributed immensely to the consolidation of another sense of community in the school, which was autonomously guided by the students.

Throughout the month of the occupation, they dedicated part of their time to the organization of routine, but also to mapping and cleaning spaces, as well as organizing classes, workshops and debates on design and the crisis. They also engaged collectively in design projects that generated income for the expenses of the occupation, such as food and cleaning. However, starting April $17^{\text {th }}$, when classes resumed, the occupation was demobilized. Nonetheless, the feeling that it sparked brought forward another important layer of life in the school. After all, with the occupation the students claimed the legitimacy of their sense of belonging to that place. Moreover, their right to live at the school on their own terms.

Some of the spaces activated or energized during the occupation continued to operate through collaborative management, even after it had ended. Two projects stand out, the 'Green Spaces' and 'Colaboratório', which were already organized according to principles of shared management of spaces and activities before the occupation, and which continued to exist, in the same terms; and the collaborative kitchen, assembled by the occupants, in which students, professors and staff began to cook and eat together, often in collective efforts. In these spaces, the occupation is ongoing.

According to Eduardo Viveiros de Castro, in a text entitled 'Os involuntários da pátria' ('the un-volunteers of the country'), 'belonging to the land, instead of being the owner of it, is what defines the indigenous. And, in this sense, many peoples and communities in Brazil, besides the Indigenous people, can say, because they feel this, that they are indigenous people much more than they are citizens' (Viveiros de Castro 2017: 05). According to this statement, indigenous people would include all those who are part of a community connected to a specific place, and who, with this, recognize themselves as belonging to the land, claiming their right to live in it.

Obviously, the students who occupied ESDI did not claim recognition as Indigenous people. However, they proclaimed the same double affirmation: belonging to the school and the right to remain there, above and beyond what is imposed on them by those who think that they have the right to regulate what can happen there. Like many Indigenous groups who claim the right to remember their belonging to a particular land, which, consequently, implies a claim to the right to live in it, the students who occupied ESDI allowed themselves to remember and thus to remind others that they were also part of that place.

Like the chthonic ones imagined by Haraway (2016: 2, 71), the students who occupied the school were reclaiming their belonging to the place. In doing so, they did not point to future possibilities of overcoming the crisis, or to some kind of restoration of a previous ideal, but, staying with the trouble, they simply affirmed their commitment 'to the more modest possibilities of partial recuperation and getting on together' (Haraway 2016: 10). After all, nothing would be solved or guaranteed with their occupation. Betting on risky co-makings (Haraway 2016: 14), they only hinted that in the midst of precariousness and uncertainty, it was possible to revolutionize, responding creatively to contingencies, in resurgence. 
With this sympoietic attitude, which reconfigured the distribution of information and control over the school, they ended up demonstrating the sheer impossibility of delimiting power in the management of that institution and the situation it was in at that moment. After all, if nobody told us to close the university, there was also no one who could guarantee its operation. Everything was happening as if there was not even the possibility of deliberating on what to do. Moreover, if alternative means of securing that the school remain open could not be envisaged, much less could one plan for the future.

With this, the students' occupation at ESDI seemed to mean that we would only be fit to face what threatened us if we also became able to transform ourselves by means of strange and risky co-makings that could build effective new collectives. If we were to relearn how to conjugate worlds with partial connections, we could become capable of inventing pedagogical and technological ways of rendering each other capable of responding to problems novel to all of us (Haraway 2016: 18). The task was then of the same sort as that commented on by Haraway: 'learning to live and die well with each other in a thick present' (Haraway 2016: 1). Cultivating these 'arts for living on a damaged planet that demand sympoietic thinking and action' (Haraway 2016: 67), we can learn how to live in ruins and to build unexpected sympoietic architectures and places for living together with difference.

But these differences involved not only the chthonic critters I have evoked so far. We only bumped into them because we crouched down into the muddy waters of Boqueirão, examining some of Big Foot's tracks (Ginzburg 1983: 95). Making visible the passage of this strange and gigantic creature that has passed by, these muddy footprints led the way so that we could feel the miasmic emanations of the lagoon once again, which never ceased to circle by, but to which we, little by little, have become insensible. Inebriated by the miasma that is always being expelled, we finally found these other worlds, where it is no longer possible to distinguish between critters, water, sky, and earth, or between past, present, and future. But this is only the beginning.

\section{Staying with the trouble, we remake community and care. But this is just the beginning...}

Settled on the soil that buried the Lagoa do Boqueirão, this small and old industrial design school was able to take the movement of openness and care to a threshold where activating the sense of community went hand in hand with revising the forms of organization and administration, as well as revising ways of teaching design. And, as if that wasn't enough, of revising what many believe lies at the 'core' of the practice of design, namely the notion of prediction.

These experiments, along with the sense of community that inspired them, may seem no more than mere improvisatory and inconsequential acts that serve only to circumstantially mitigate the effects of the crisis. However, just like the doors and windows remade by another materiality, they multiply, thereby creating, in fact, a new and other school. It is not new because it rejects or refuses the past, nor because it wishes to promote a remodelled futuristic self-image as part of a novel project, but rather the same new/other school that corresponds with what is happening here and now.

Thus, in ESDI, the ways in which we reacted to the crisis point not only to ways of reinventing the school; they also broaden the debate about the notion of the future, traditionally understood as a fundamental characteristic of design practice. After all, in the industrial rhetoric that informs this professional practice, things should first be idealized, then modelled, tested, fabricated, marketed, and ultimately consumed. According to this version, the industrial designers are to be those who devote themselves to the development of things as products for the industry. Planning today what would only come into circulation a little later, in a more or less near future. Designing would then have to do with ideas of prediction, prescription, foresight (Ingold, Gatt 2013). 
As the crisis surprises us daily with new and unsuspected challenges, even more so after the Brazilian presidential election of 2018, the prediction supposedly intrinsic to the activity of design seems incompatible with the urgencies of these challenges and the scarcity of the resources available to meet them. Thus, the responses we rehearsed through continual experimentation seemed to indicate fundamental transformations in the temporal emphases that guide the practice of design, since, more than planning artefacts and means of communication envisioning an implementation in the future, it is necessary to take action and to respond in the present.

It seems, then, that industrial logic no longer serves us. If it was one of the last areas of knowledge to emerge from modern Western thought, believing, then, in great separations, this and that - creation, production, consumption, us and them - designers, consumers and users, maybe it's time to realize that this same modern project, to which many of us designers devote our faith, no longer fits us. Or is it that we no longer fit in? Have we ever fit in?

Speaking to designers, Bruno Latour (2008) invites us to abandon the dogmas of Promethean modernism, to consider rethinking the design profession in a post-Promethean era. Can we imagine Prometheus seizing fire in a cautious, prudent, careful manner? This other Prometheus, would he be a designer designing with caution? Drawing things together? Latour thus raises the question: "How can we draw together matters of concern, so as to offer to political dispute an overview, or at least a view, of the difficulties in which we are going to be entangled every time we are going to have to modify the practical details of our material existence?" (Latour 2008: 11).

Back to ESDI. In Haraway's terms, we could speak of a chthonic design, or the design of chthonic ones, which is no longer concerned with designing, but with the ability to respond, thus developing their own responseabilities in precarious times. A design that 'through this ongoing quest for displacement and change, strives to continually maintain experimentation' (Lenskjold, Olander, Halse 2015:67), like what the researchers of the CoDesign Research Center (Code/KADK) propose with their notion of 'minor design activism' (2015: idem). By rehearsing other conversational dispositifs (Anastassakis, Szaniecki 2016), through open-ended experiments, this kind of design seeks to challenge prescriptive agendas and, above all, to reconfigure collective relations.

In assuming that we can only build because we dwell (Hallam, Ingold 2014: 04), this sympoietic way of thinking and designing does not solve any crisis, nor does it even propose alternative solutions. Reclaiming, it starts to recover the ability to live and die well with difference, and thus to correspond, honouring every experience 'we care for, as "not ours" but rather as "animating" us, making us witness to what is not us' (Stengers 2012). By reclaiming such a process of correspondence of agencing (Ingold 2017, 2018) it creates other presences, other modes of response, in resurgence.

Invoking these processes of 'becoming-with' (Haraway 2016: 25), understanding interpenetration as condition (Ingold 2016: 12), and retrieving the ways in which companion species (Haraway 2016: 29) get along together (Haraway 2016: 25-9), we find the clues that allow us to escape from a simplistic reading of the commoning process. After all, one must consider, as Ingold suggests, following the philosopher John Dewey's propositions, the practices involved in these processes. Thus, there can be no commoning without variation, nor variation without commoning. According to this perspective, commoning and variation are codependent.

This notion of 'variation-in-commoning', Ingold argues, 'anticipates the idea of interstitial differentiation' (Ingold 2016: 15). Paying attention to this interstitial arena of experience of the interval - midstream - where there are no subjects before actions, is what he proposes through the notion of 'correspondence of agencing' (Ingold 2016: 17). Following these correspondences (Ingold 2015, 2016, 2017), established through improbable collaborations (Haraway 2016: 136), and paying attention to both the knots and the intervals forged in them, Ingold and Haraway whisper in our ears stories told in otherwise muted registers, stories that require reading with all of our senses. 
Among the curious outcomes of this process was the research carried out by Master's Degree student Pedro Themoteo and PhD students Diego Costa, Pedro Biz and Pedro Costa. Through their involvement with the school's garden, they began to manufacture artefacts along with the trees (Themoteo, Biz, Costa 2017) and to cultivate colonies of bacteria (kombucha) with which to develop materials and products, such as a wallet made from bacterial cellulose (Costa, Biz 2017). If, in ESDI, we design even with the trees and the bacteria, we should ask ourselves, more broadly, what can designing be in times of turbulence. With our tentacles gathered in an unusual meshwork, we reach the bottom of the Lagoa do Boqueirão and the water reservoir atop a building. Like trees, bacteria, protozoa, and termites, we create paths. New beginnings. A fresh start. Intermediations. Metamorphoses.

But for now, hand in hand with Bergmiller, Haraway, and Ingold, I set this story aside and settle idly under the shade of a tree by the muddy waters of the Boqueirão. It is now one of the avocado trees that we had to prune drastically because it had become hollow, devoured by our companions, the termites. Curiously, soon after the pruning, both trees began do bud with strength and vigour.

As I lie down against the tree, inebriated by the miasmic emanations the lagoon insists on releasing, I end up falling asleep to the sound of the voice of one of my traveling companions, murmuring affectionately in my ears: 'How should we define it? What is tree and what is not-tree? Where does the tree end and the rest of the world begin? (...) Every tree is a knot, and the characteristic feature of all knots is that their constitutive threads are joined not end to end but in the middle, with trailing ends that go in search of other threads to bind with. Life is a meshwork' (Ingold 2017:34-35). So, my dear avocado tree, let's take a walk on the wild side.

\section{Acknowledgments}

In this paper, I re-elaborate some arguments developed in partnership with Professor Marcos Martins, vice-director of ESDI/UERJ between March 2016 and December 2018, following an invitation from John Walters, editor of Eye Magazine, to publish a paper on the ways in which, at ESDI, we rehearsed responses to the crisis affecting UERJ (Anastassakis, Martins 2018). Next, upon Tim Ingold's invitation, I had the opportunity to expand that debate preparing the chapter 'Bigfoot and the Termites remaking community and care at an old design school', that would be part of a compilation on architectural symbioses organized by Ingold and Julien Dugnoille. Upon this invitation, as a visiting researcher, I followed the research activities of the project "Knowing from the inside" coordinated by Tim Ingold in the Department of Anthropology at the University of Aberdeen. At the time, Prof. Ingold read and revised the text attentively, which contributed immensely to its development. I thank everyone mentioned above for creating opportunities for me to embark on this endeavor. In addition, I would like to thank Frederico Duarte for putting us in contact with John Walters; Marcos Martins, for the partnership; Tim Ingold, for encouraging me to write about this experience considering it as an 'architectural symbiosis', and for the accurate reading, comments and reviews; André Aranha, Carolina Correa dos Santos and Letícia Carvalho, for reading and commenting; Mariana Chianca, for the support during the writing process; my undergraduate and graduate students, who, at different times, read and commented on the text; and those who participated in the seminars where I presented preliminary versions of this essay: 1) 'Entremeios em tempos de turbulência', organized by Barbara Szaniecki and myself in November 2017; 2) "SMARTIE", organized by Els Lagrou, Marco Antonio Gonçalves, Tatiana Bacal and Wagner Chaves at the Post-Graduate Program of Sociology and Anthropology, Federal University of Rio de Janeiro in April 2018; 3) 'A Confluence of ways: Design, Anthropology and Artistic Practices', organized by Caroline Gatt and Valeria Lembo in May 2018, as part of Knowing from the Inside, a research project coordinated by Tim Ingold in the Department of Anthropology, University of Aberdeen. 
Received: May 29, 2018

Approved: January 21, 2018

Translated by Mariana Chianca

Revised by Tim Ingold and Luiz Costa

\section{References}

ANASTASSAKIS, Z. 2011. Triunfos e Impasses: Lina Bo Bardi, Aloisio Magalhães e a institucionalização do design no Brasil. PhD Thesis present to the Programa de Pós-Graduação em Antropologia, Museu Nacional, Universidade Federal do Rio de Janeiro.

ANASTASSAKIS, Z. 2014. Triunfos e Impasses: Lina Bo Bardi, Aloisio Magalhães e o design no Brasil. Rio de Janeiro: Lamparina Editora.

ANASTASSAKIS, Z.; MARTINS, M. Winter 2018. "Smoke signals from Brazil". Eye Magazine, n. 95, vol. 24. Available at: http://www.eyemagazine.com/feature/article/smoke-signals-from-brazil

ANASTASSAKIS, Z.; SZANIECKI, B. 2016. "Conversation Dispositifs: Towards a Transdisciplinary Design Anthropological Approach”. In: R. C. Smith; T. Otto; K. T. Vangkilde; J. Halse; T. Binder; M. Kjaersgaard (eds.), Design Anthropological Futures: exploring emergence, intervention and formation. London, New York: Bloomsbury. pp. 121-138.

COSTA, P. Z. R. da C.; BIZ, P. 2017. "Cultivando materiais: o uso da celulose bacteriana no design de produtos”. Anais do 3o Simpósio de Pós-Graduação em Design da ESDI. Mimeo.

CASTRO JÚNIOR, P. R. 2002. Dinâmica da água em campos de Murundus do planalto dos Parecis. $\mathrm{PhD}$ Thesis (Physical Geography). Programa de Pós-Graduação em Geografia, Universidade de São Paulo, São Paulo. 193 p.

FONTES, L. R. 2014. “Termitologia, a ciência dos cupins”. Interview. Observatório da Imprensa, ed. 788. Available at: http://observatoriodaimprensa.com.br/mosaico/_ed788_termitologia_a_ciencia_dos_ cupins/ Accessed: 27 March 2019.

GINZBURG, C. 1983. "Morelli, Freud and Sherlock Holmes: clues and scientific method". In: U. Eco; T. A. Sebeok (eds.), The Sign of Three: Dupin, Holmes, Peirce. Bloomington: Indiana University Press. pp. 81-118.

HALLAM, E.; INGOLD, T. (eds.). 2014. Making and Growing. Anthropological Studies of Organisms and Artefacts. Farnham: Ashgate.

HARAWAY, D. 2016. Staying with the trouble: making kin in the Chthulucene. Durham and London: Duke University Press.

INGOLD, T. 2011. Being Alive: Essays on Movement, Knowledge and Description. London: Routledge. . 2015. The life of lines. London: Routledge. . 2016. "On human correspondence". Journal of the Royal Anthropological Institute (N.S.), 23(1): 9-27. . 2017. Correspondences. Aberdeen: University of Aberdeen. . 2018. Anthropology and/as education. London: Routledge.

INGOLD, T.; GATT, C. 2013. "From description to correspondence: Anthropology in real time". Design Anthropology: Theory and Practice, eds. W. Gunn, T. Otto and R. Charlotte-Smith. London: Bloomsbury, pp. 139-158. 
LATOUR, B. 2008. "A Cautious Prometheus. A few steps towards a philosophy of design (with special attention to Peter Sloterdijk)". Keynote Lecture, Networks of Design Meeting, Design History Society, Falmouth, Cornwall. Available at: http://www.bruno-latour.fr/sites/default/files/112-DESIGNCORNWALLGB.pdf Accessed: 27 March 2019.

LEMINSKI, P. 1985. Distraídos venceremos. São Paulo: Brasiliense.

LENSKJOLD, T. U.; OLANDER, S.; HALSE, J. 2015. "Minor design activism: prompting change from within". Design Issues, 31(4): 67-78.

MARTINS, L.; MARTINS, R. 2006. "Os miasmas e a teoria microbiana das doenças" [Miasma and the microbian theory of diseases]. Scientific American Brasil [Série História] (6), pp. 68-73.

MAUSS, M. 1923-24. “Essai sur le don: forme et raison de l'échange dans les sociétés archaiques". L’Année Sociologique (N.S.), 1: 30-186.

OcUPA ESDI. 2017. Text published by OcUPA ESDI in social media and throughout the school campus, 03/14/2017.

STENGERS, I. 2012. "Reclaiming Animism”. E-flux, Journal \#36. Available at: http://www.e-flux.com/ journal/36/61245/reclaiming-animism/ Accessed: 27 March 2019.

STRATHERN, M. 1991. Partial Connections. Lanham: Rowman and Littlefield.

THEMOTEO, P.; BIZ, P.; COSTA, D. 2017. "Design plantado: questões para desenvolvimento do método". Anais do 3을 Simpósio de Pós-Graduação em Design da ESDI. Mimeo.

TINOCO, R. M. 2016. "A sociedade anônima dos cupins”. Revista Super Interessante. Available at: https:||super. abril.com.br/ciencia/a-sociedade-anonima-dos-cupins/ Accessed: 27 March 2019.

VIVEIROS DE CASTRO, E. 2004. "Perspectival Anthropology and the Method of Controlled Equivocation". Tipiti. Journal of the Society for the Anthropology of Lowland South America, 2(1). Available at: https:/ digitalcommons.trinity.edu/tipiti/vol2/iss1/1 Accessed: 27 March 2019.

VIVEIROS DE CASTRO, E. 2017. "Os Involuntários da Pátria”. Chão da Feira, Caderno n. 65, Série Intempestiva. Available at: http://chaodafeira.com/cadernos/os-involuntarios-da-patria/ Wikitermes. Available at: http://termite.wikidot.com/ Accessed: 27 March 2019.

\section{Zoy Anastassakis}

Associate Professor

Superior School of Industrial Design, State University of Rio de Janeiro, Rio de Janeiro/RJ, Brazil Author's email: zoy@esdi.uerj.br https://orcid.org/0000-0001-5453-0814 